\title{
PREVALENCE OF ANTINUCLEAR AUTOANTIBODIES IN THE SERUM OF NORMAL BLOOD DONORS
}

\author{
Solange Assuncion Villagra Fernandez, Alice Zoghbi Coelho Lobo, Zilda Najjar \\ Prado de Oliveira, Ligia Maria Ichimura Fukumori, Alexandre Marques Périgo \\ and Evandro A. Rivitti
}

FERNANDEZ SAV et al. - Prevalence of antinuclear autoantibodies in the serum of normal blood donors. Rev. Hosp. Clín. Fac. Med. S. Paulo 58(6):315-319, 2003.

OBJECTIVE: To examine the presence of serum antinuclear autoantibodies in a healthy population.

METHODS: Serum of 500 normal blood donors between 18 and 60 years of age were tested for the presence of autoantibodies. Antinuclear antibodies were detected by indirect immunofluorescence technique using HEp-2 epithelial cells as the substrate. The presence of dnaN was detected by indirect immunofluorescence technique using Critidia lucillae as the substrate. Anti-SSA (RO), anti-SSB (LA), anti-Sm, and anti-RNP were determined by double radial immunodiffusion.

RESULTS: In the evaluation of the presence of serum antibodies, antinuclear antibodies were detected in $22.6 \%$ of the sera. The presence of other antibodies was not significant. The majority of the titers were 1:40.

CONCLUSION: The presence of autoantibodies is not necessarily pathologic and has to be related to the age group, gender, and clinical condition of the patient.

DESCRIPTORS: Autoantibodies. Healthy population. Rheumatic diseases. Antinuclear antibodies. Autoimmunity.

Immune humoral response in the presence of autoantibodies against intracellular antigens characteristically occurs in a majority of connective tissue diseases. This phenomenon is found in systemic lupus erythematous, systemic sclerosis, Sjögren syndrome, mixed connective tissue disease, polymyositis, and dermatomyositis, among others $^{1}$.

The detection of such autoantibodies is important not only for diagnosis but also for the prognosis of the diseases, in addition to allowing clinical follow-up and treatment evaluation in many cases ${ }^{1}$.

It is relevant to point out that in healthy people and in patients with non-rheumatic conditions, such as chronic hepatic diseases, neoplasias, as well as active infections including tu- berculosis, malaria, and subacute bacterial endocarditis, these autoantibodies may be present ${ }^{1}$. In general, they are found in lower titers than those detected in autoimmune diseases. It is believed that such titers may precede the appearance of diseases in normal and asymptomatic individuals for many years ${ }^{2}$.

Previous studies have shown different prevalences of autoantibodies in healthy populations. Baig and Shere (1989), who investigated the serum of blood donors and patients without autoimmune diseases in Saudi Arabia,

From the Department of Dermatology and the Immunopathology Laboratory, Hospital das Clínicas, Faculty of Medicine, University of São Paulo - São Paulo/SP, Brazil. Received for publication on March 10, 2003. found antinuclear antibodies (ANA) present in $4.2 \%{ }^{3}$. Vlam et al. (1993) detected ANA present in $13 \%$ of normal blood donors in a Belgian population ${ }^{2}$. Vazquez-Del Mercado et al. (1995) reported that $4.7 \%$ of a Mexican population tested positive for ANA $^{4}$.

The present study intends to evaluate the prevalence of autoantibodies in healthy people in relation to gender and age group. It is important to note that it is the first such study in Brazil, one that characterizes a specific population, that of blood donors of the Pro-Blood Foundation - Hemocenter of São Paulo, aiming to obtain parameters for comparisons with other populations.

All the samples were screened for the presence of ANA using the indirect 
immunofluorescence technique in HEp-2 cells. They were also tested for the identification of antibodies against antigens extracted from the nucleus such as anti-SSA/RO, anti-SSB/LA, anti-Sm, and anti-RNP by double radial immunodiffusion. They were still tested for dnaN using indirect immunofluorescence (IIF) technique with Crithidia luciliae as the substrate.

In the blood bank, samples are habitually tested for infectious diseases such as Chagas disease, syphilis, hepatitis B and C, HTLV-1 and HTVL-2, and HIV-1 and HIV-2, that may contraindicate the utilization of the blood taken.

This study was approved by the Institutional Ethical Committee. The volunteers who had significant titers (ANA $>1: 160)$ for the studied parameters were informed of that and were re-examined for any disease that could be clinically confirmed. They received follow-up evaluation and orientation when necessary.

\section{PATIENTS AND METHODS}

\section{Blood samples collection}

The blood samples were collected only after the volunteers had agreed to take part in the study and after they signed the consent form.. Five hundred consecutive blood samples of volunteer donors (182 women and 318 men), between 18 and 60 years of age, with no clinical symptoms of any disease, were analyzed (Fig. 1). They were obtained from the Pro-Blood Foundation - Hemocenter of São Paulo.

\section{Autoantibody detection}

After collection in plain red-top tubes, the blood samples were centrifuged (10 minutes at $2000 \mathrm{rpm}$ ), and the serum was separated into aliquots for performing the autoantibody-detection tests.
The indirect immunofluorescence (IIF) technique to detect antinuclear antibodies, described by Holbrow, Weir, and Jonhson in 1957, was used in slides covered with commercially obtained (Hemagen ${ }^{\circledR}$ ) HEp-2 cells (epithelial cells of human larynx carcinoma). The usage of human cells guarantees the presence of nuclear antigens in such a concentration that enables the confirmation of the presence of antibodies in the serum.

At first, a screening test was carried out, in which serum samples were diluted in phosphate-buffered saline, $\mathrm{pH}$ 7.4 (PBS) to a titer of 1:40 to detect positive reaction and characterization of the fluorescence pattern. The positive samples were titered until testing negative.

The HEp-2 cells were incubated with the donor's serum samples in a humid and dark camera for 30 minutes and were then washed in PBS. Afterwards they were incubated with human anti-IgG antibody marked with fluorescein isothiocyanate. After being washed again, the slides were mounted with buffered glycerine $\mathrm{pH}$ 8. A Zeiss microscope equipped for epiluminescence was used for reading the slides.

In order to detect native anti-DNA autoantibodies (DNAn), the indirect immunofluorescence (IIF) technique was used in slides covered with Crithidia lucillae (a protozoan that is rich in kinetoplast DNA) obtained from the Department of Rheumatology of our Institution.

The slides were incubated with the samples diluted 1:20 in Tris-buffered saline, $\mathrm{pH} 7.5$ (TBS) and were then washed and incubated with human anti-IgG antibody (SIGMA brand) marked with fluorescein isothiocyanate. A Zeiss microscope equipped for epiluminescence was used for reading the slides (immersion objective).

The double radial immunodiffusion technique, described by $\mathrm{O}$. Ouchterlony in 1949, was used to in- vestigate anti-SSA (RO), anti-SSB (LA), anti-Sm, and anti-RNP antibodies. The reaction was run on $0.6 \%$ agarose. The sources of antigens were extracted from the human spleen for SSA and rabbit thymus extract (Sigma brand) for anti-SSB, anti-Sm, and antiRNP. The positive controls were commercially obtained (IMMCO brand).

Petri plates with agarose gel were perforated to restrain the samples (nondiluted serum), the controls, and the source of antigen. The plates were visually analyzed over a period of 24 to 48 hours for observation of the formation (positive) or non-formation (negative) of lines of immunoprecipitation between the samples and the controls.

\section{Infectious diseases serology}

The Pro-Blood Foundation Hemocenter of São Paulo uses the following techniques to investigate infectious diseases in the blood of donors: ELISA and VDRL for syphilis; ELISA, and if positive, Western - Blot for HIV; ELISA for HTLV; ELISA, indirect hemaglutination and indirect immunofluorescence (IIF) for Chagas disease and ELISA for hepatitis B.

\section{Statistical analysis}

The statistical analysis was performed by the Department of Preventive Medicine of our Institution. The c2 test was used, adopting the value of $P$ less than or equal to $5 \%$ as the indicator for statistical significance. The statistical analysis was carried out with the software STATA ${ }^{\text {TM }}$ (Statistical/ Data Analysis), version 7.0.

\section{RESULTS}

The study involved 318 men $(63.6 \%)$ and 182 women $(36.4 \%)$. The average age of the donors was 33.1 
years $($ standard deviation $=9.7$ years of age). No association was found between gender and age of the donors $(P$ $=0.27$ ) (Table 1; Fig.1). Out of the 500 donors included in the sample, 113 were positive for ANA, representing a prevalence of $22.6 \%\left(\mathrm{CI}_{95 \%}: 18.9 \%\right.$ to $26.3 \%$ ) as shown in figure 2 . Among the donors who presented ANA+, 73 (64.6\%) had a titer of 1:40, $23(20.4 \%)$ a titer of $1: 80,10(8.8 \%)$ a titer of $1: 160$, and $7(6.2 \%)$ a titer equal or higher than 1:320. Out of this last group, 1 donor presented a titer of 1:320, 2 donors 1:1280, 2 others $1: 2560,1$ a titer of 1:5120, and another of 1:10240. Titers of ANA equal to or higher than 1:320 are considered pathological in the literature, and 7 of the 500 donors included in the study presented titers in this category, which corresponds to a prevalence of $1.4 \%$ $\left(\mathrm{CI}_{95 \%}: 0.3\right.$ to 2.4$)$. The prevalence of ANA among the donors included in the study according to the different titers found is shown in table 2. The prevalence of other autoantibodies was very low: 1 donor presented anti-SM+ (and did not present ANA+), and 2 other donors presented anti-RO+ (one with ANA+ 1:40 and another with ANA+ 1:10240). The association between gender and age group and the presence of ANA+ (in any titer) is shown in table 3. Female blood donors presented a higher risk of presenting ANA+ (PR $=1.66 ; \mathrm{CI}_{95 \%}: 1.20$ to 2.28$)$. As for the age group, donors under 40 years of age presented a tendency to a smaller prevalence of ANA+, with no statistical significance. The risk of presenting ANA+ according to gender did not present any significant alterations after the age adjustment $(\mathrm{PR}=1.62$; $\mathrm{CI}_{95 \%}: 1.18$ to 2.21 ), which means that age was not a confounding variable for this association. Only a few donors presented ANA titers equal to or higher than 1:320, and this hindered the investigation of the characteristics associated with such titers. There was a
Table 1 - Distribution by gender and age group of the volunteer blood donors included in the study ( $\mathrm{n}=500)$.

\begin{tabular}{|c|c|c|c|c|c|c|}
\hline \multirow[b]{2}{*}{ Age group } & \multicolumn{2}{|c|}{ MEN } & \multicolumn{2}{|c|}{ WOMEN } & \multicolumn{2}{|c|}{ TOTAL } \\
\hline & $\mathrm{N}$ & $\%$ & $\mathrm{~N}$ & $\%$ & $\mathrm{~N}$ & $\%$ \\
\hline Up to 30 & 149 & 46.9 & 84 & 46.1 & 233 & 46.6 \\
\hline 31 to 40 & 109 & 34.3 & 52 & 28.6 & 161 & 32.2 \\
\hline 41 to 50 & 38 & 11.9 & 32 & 17.6 & 70 & 14.0 \\
\hline 51 to 60 & 22 & 6.9 & 14 & 7.7 & 36 & 7.2 \\
\hline
\end{tabular}

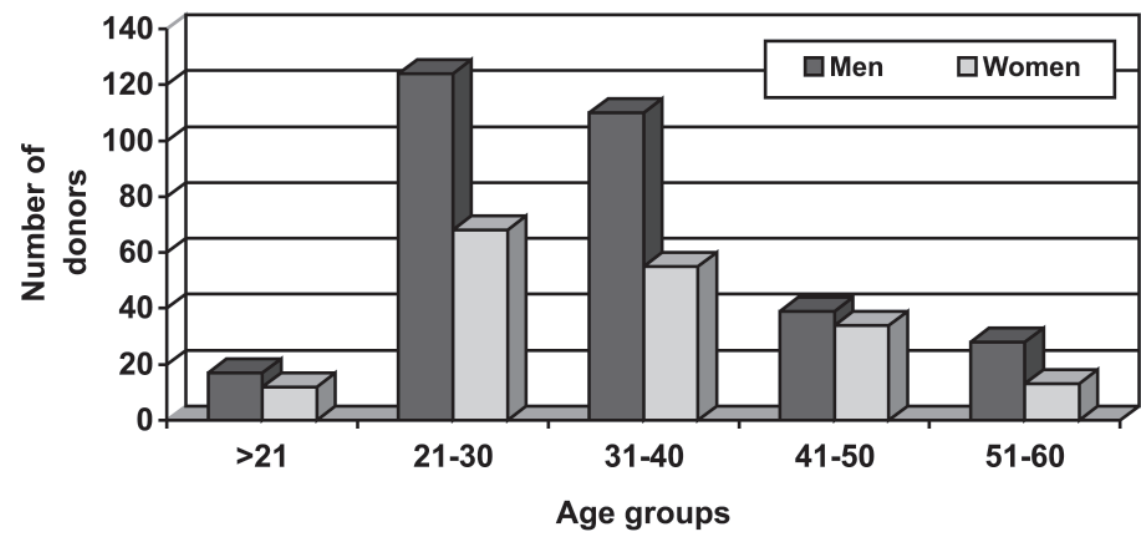

Figure 1 - Total number of blood donors, distributed according to gender and age group.

Table 2 - Prevalence of ANA+ of the volunteer blood donors included in the study, according to different titers $(n=500)$.

\begin{tabular}{lccc}
\hline ANA (titer) & $\mathrm{N}$ & Prevalence $(\%)$ & $\mathrm{CI}_{95 \%}(\%)$ \\
\hline $1: 40$ & 73 & 14.6 & 11.5 to 17.7 \\
$1: 80$ & 23 & 4.6 & 2.8 to 6.4 \\
$1: 160$ & 10 & 2.0 & 0.8 to 3.2 \\
$1: 320$ or more & 7 & 1.4 & 0.3 to 2.4 \\
Any titer & 113 & 22.6 & 18.9 to 26.3 \\
\hline
\end{tabular}

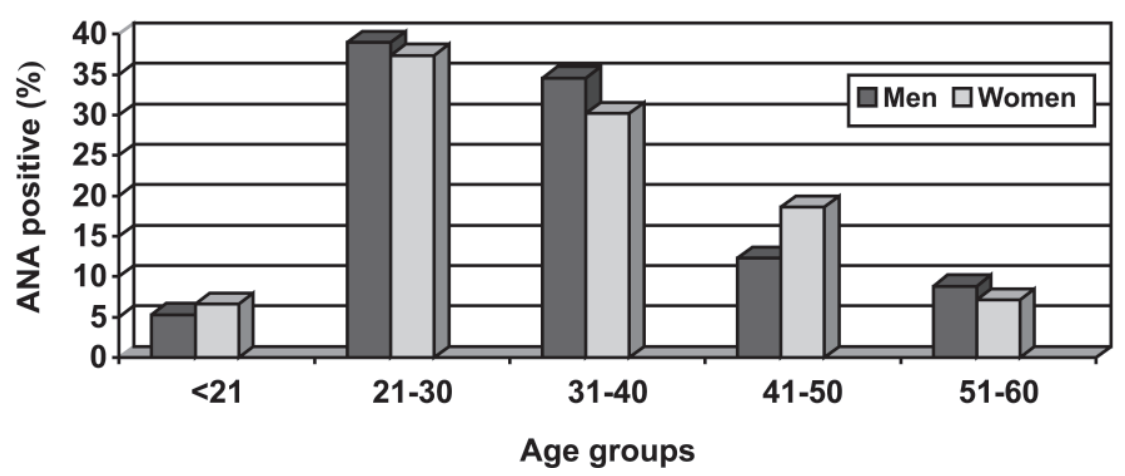

Figure 2 - Percentage of antinuclear antibodies positive in each age group, according to gender. 
marginally significant tendency towards the presence of higher titers of $\mathrm{ANA}+\left(\mathrm{PR}=4.4 ; \mathrm{CI}_{95 \%}: 0.9\right.$ to 22.3$)$ among females, and no association was found between age group and titers of ANA higher than 1:320 (Table 4, Fig.3).

As for serologies for infectious diseases, only 2 donors presented positive serology for hepatitis B (anti-HBc) and were ANA positive with low titers (1:40).

\section{DISCUSSION}

Antinuclear antibodies (ANA) are present in some autoimmune diseases and in other non-autoimmune conditions, as mentioned before. In the autoimmune diseases, testing for ANA is considered a useful screening test due to its high sensitivity and low specificity. For instance, in case of systemic lupus erythematous, a positive test with titers higher than 1:40 and 1:80 presents a positive predictive value of $15 \%$ to $35 \%$, indicating the need to complement the investigation with tests for other autoantibodies such as anti-DNAn, anti-RO, anti-Sm, and anti-LA ${ }^{2}$. In face of a positive test for ANA, in addition to the patient clinical profile, some other conditions have to be taken into consideration, such as the presence of positive serologies for hepatitis B and C, HIV, HTLV, Chagas disease, and syphilis, since patients with such diseases may test positive for ANA although in low titers ${ }^{2}$. In the present study, 2 out of the 112 ANApositive samples presented positive serology for hepatitis B (ANA being found in low titers: 1:40), which may represent a false positive result due to the hepatitis. That is why it is always important to exclude the possibility of any infectious disease in face of a positive result for ANA in low titers.

In the present study, the prevalence of ANA in the general population was

Table 3 - Prevalence ratios of ANA+ in any titer, according to age group and gender.

\begin{tabular}{lccclll}
\hline Characteristic & Total & ANA & $\%$ & PR & CI $_{95 \%}$ & $P$ \\
\hline Gender & & & & & & \\
Male & 318 & 58 & 18.2 & 1.0 & & \\
Female & 182 & 55 & 30.2 & 1.66 & 1.20 to 2.28 & 0.002 \\
\hline Age group & & & & & & \\
41 or older & 106 & 30 & 28.3 & 1.0 & & \\
Up to 40 & 394 & 83 & 21.1 & 0.74 & 0.52 to 1.06 & 0.11 \\
\hline
\end{tabular}

Table 4 - Prevalence ratios of antinuclear antibodies titers equal to or higher than 1:320, according to gender and age group.

\begin{tabular}{lclllll}
\hline Characteristic & Total & FAN + & $\%$ & PR & $\mathrm{CI}_{95 \%}$ & $P>1: 320$ \\
\hline Gender & 318 & 2 & 0.6 & 1.0 & & \\
Male & 182 & 5 & 2.7 & 4.4 & 0.9 to 22.3 & 0.06 \\
Female & 106 & 1 & 0.9 & 1.0 & & \\
\hline Age group & & & 1.5 & 1.6 & 0.2 to 13.2 & 0.65 \\
41 or older & 106 & 6 & &
\end{tabular}

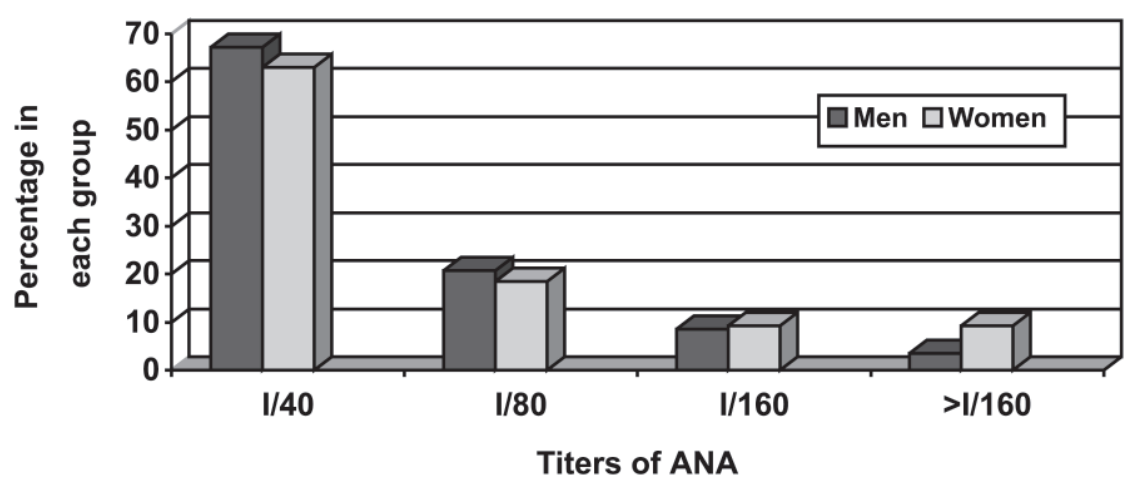

Figure 3 - Percentage of antinuclear antibodies positive in each titer group, according to gender.

$22.6 \%$, higher than the prevalences found in the literature, which vary from $4 \%$ to $13 \% \%^{3,5,6,7}$. The majority had low titers $(83.9 \%$ with titers of $1: 40$ and $1: 80)$, which is in accordance with the results obtained by other authors ${ }^{2,8}$. In 10 donors $(8.9 \%)$, the ANA titer was $1: 160$, which is considered an intermediate value ${ }^{2}$. Since there are few studies of this kind in the literature and most of them deal with the European population, which does not have the same ethnic characteristics as ours, it is difficult to determine whether this incompatible result is due to any idi- osyncrasy of the sample studied. In order to clarify this point, it would be preferable if this study were applied in other populations. Taking into consideration that 8 of the observed donors presented ANA $>1: 160$, a titer considered significant for the diagnosis of collagenosis, it is advisable that such donors, although clinically healthy, should receive follow-up evaluation in order to detect any sign of the development of an autoimmune disease. Two of the observed donors presented positive anti-RO, one of them with an ANA titer of 1:160 and the other ANA 
titer of 1:40. The positivity of such an antibody associated with ANA significantly increases the possibility of an autoimmune disease that is not clinically detectable at the present moment or that has not yet developed. Therefore, these 2 donors should be segregated from the ANA+ assuredly healthy population, reducing the positivity of such an autoantibody in the healthy individuals to $20.6 \%$. Concerning gender, there was a higher positivity of ANA among females, which agrees with the available data in the literature $3,5,6,9$. As for ANA distribution among age groups, there was no statistical difference, which contra- dicts the observations reported in the literature of higher positivity of autoantibodies, including those of ANA, in the elderly as a result of the loss of autoregulation of the immune system due to senescence ${ }^{3,5,10}$.

\section{CONCLUSION}

This paper reports on a study of a specific population of blood donors between 18 and 60 years of age. Although it does not cover all the age groups, it allows the following conclusions based on the ones observed:

1. ANA may be positive in low titers in the normal population, not necessarily being an indicator of collagenosis.

2. Infectious contagious diseases may lead to positivity for ANA although in low titers.

3. ANA positivity in healthy individuals was higher among females.

4. Positivity for other autoantibodies was low and not always related to the positivity of ANA.

5. The present study leads the way to population studies in Brazil so that we may have a chart of ANA and of other autoantibody positivity in different population groups in our country.

\section{RESUMO}

FERNANDEZ SAV e col. - Prevalência de auto-anticorpos antinucleares no soro de doadores de sangue normais. Rev. Hosp. Clín. Fac. Med. S. Paulo 58(6):315-319, 2003.

OBJETIVO: O objetivo deste trabalho foi detectar a presença de autoanticorpos em pessoas sadias.

MÉTODOS: Foi estudado o soro de 500 doadores de sangue sadios, com idade entre 18 e 60 anos. Anti- corpo antinuclear foi detectado por imunofluorescência indireta usando células Hep-2 como substrato. A pesquisa de anti-DNA-nativo (DNA-n) foi feita com a técnica de imunofluorescência indireta usando Critidia lucillae como substrato. A pesquisa de anti-SSA, anti-SSB, anti-Sm e antiRNP foi feita utilizando a técnica de imunodifusão radial dupla.

REUSLTADOS: A presença de anticorpo antinuclear foi detectada em $22,6 \%$ das amostras estudadas. A mai- oria apresentou títulos 1/40. A presença de outros anticorpos não foi significativa.

CONCLUSÃO: A presença de autoanticorpos não é necessariamente patológica e deve ser correlacionada à idade, sexo e condição clínica do paciente.

DESCRITORES: Autoanticorpos. População Sadia. Doenças Reumáticas. Anticorpos Antinucleares. Autoimunidade.

\section{REFERENCES}

1. Von Mühlen CA, Tan EM. Autoantibodies in the diagnosis of systemic rheumatic diseases. Semin Arthritis Rheum 1995; 24(5):323-58.

2. De Vlam K, De Keyser F, Verbruggen G, et al. Detection and identification of antinuclear autoantibodies in the serum of normal blood donors. Clin Exp Rheumatol 1993; 11(4):393-7.

3. Baig MM, Shere SJ. Prevalence of autoantibodies in Saudi population. J Med 1989; 20(3,4):286-90.

4. Vazquez-Del Mercado M, Gonzalez-Bernaldez M, Garcia-De La Torre I. Prevalence of antinuclear antibodies in a Huichol population of Mexico. Lupus 1995; 4(2):164-5.

5. Manoussakis MN, Tzioufas AG, Silis MP, et al. High prevalence of anti-cardiolipin and other autoantibodies in a healthy elderly population. Clin Exp Immunol 1987; 69(3):557-65.
6. Goemaere S, Ackerman C, Ghoethals K, et al. Onset of symptoms of rheumatoid arthrits and relation to age, sex and menopausal transition. J Rheumatol 1990; 17(12):1620-2.

7. Azizah MR, Shahnaz M, Zulkifli MN, et al. Anti-nuclear, antimitochondrial, anti-smooth muscle and anti-parietal cell antibodies in the healthy Malaysian population. Malays J Pathol $1955 ; 17(2): 83-6$.

8. Tan EM, Feltkamp TE, Smolen JS, et al. Range of antinuclear antibodies in "healthy" individuals. Arthritis Rheum 1997; 40(9):1601-11.

9. Lahita RG. Sex steroids and the rheumatic diseases. Arthritis Rheum $1985 ; 28(2): 121-6$.

10. Makinodan T, Kay MM. Age influence on the immune system. Adv Immunol 1980; 29:287-330. 